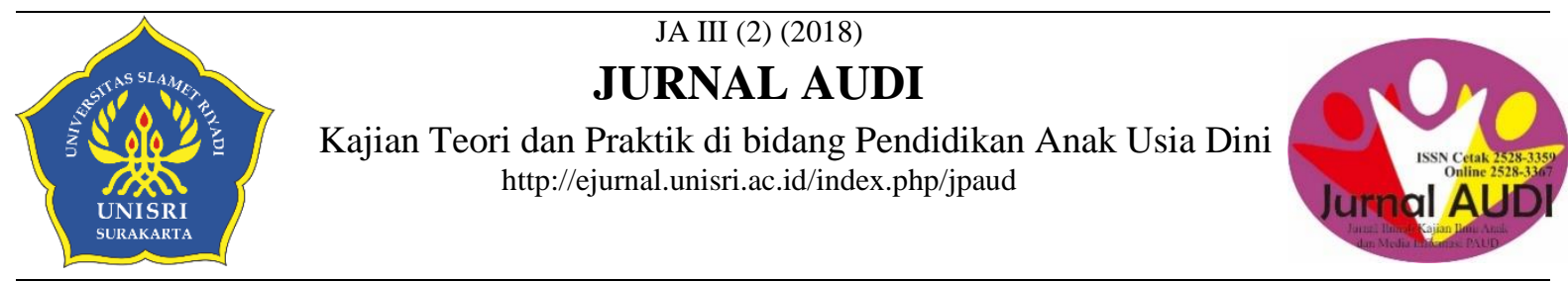

\title{
EDUPARENT BAGI ORANG TUA SISWA TK DHARMA WANITA SULUK
} DLOPO KABUPATEN MADIUN

\begin{tabular}{|c|c|}
\hline & $\begin{array}{l}\text { M. Fadlillah }{ }^{1} \text {, Betty Yulia Wulansari }{ }^{2} \\
\text { Universitas Muhammadiyah Ponorogo }\end{array}$ \\
\hline Info Artikel & Abstrak \\
\hline $\begin{array}{l}\text { Sejarah Artikel: } \\
\text { Diterima November } \\
2018 \\
\text { Disetujui November } \\
2018 \\
\text { Dipublikasikan } \\
\text { Desember } 2018\end{array}$ & $\begin{array}{l}\text { Tujuan utama kegiatan pengabdian kepada masyarakat ini adalah untuk memberikan } \\
\text { pendidikan keorangtuaan kepada orang tua siswa di TK Dharma Wanita Suluk Dlopo } \\
\text { Kabupaten Madiun. Metode pengabdian dilakukan dengan mengadakan sosialisasi } \\
\text { melalu seminar eduparent (pendidikan keorangtuaan). Tema eduparent dalam } \\
\text { kegiatan pengabdian ini yaitu melatih kemandirian anak usia dini. Sasaran } \\
\text { pengabdian ini adalah orang tua siswa di TK Dharma Wanita Suluk Dlopo } \\
\text { Kabupaten Madiun. Hasil kegiatan pengabdian ini adalah orang tua siswa mampu } \\
\text { mengetahui dan memahami perannya dalam mengasuh dan memperlakukan anak, } \\
\text { khususnya dalam melatih kemandirian anak usia dini. Orang tua siswa sangat } \\
\text { antusias mengikuti kegiata dari awal sampai selesai, sehingga mereka mendapatkan } \\
\text { wawasan dalam melatih kemandirian anak usia dini sesuai dengan tahap } \\
\text { perkembangannya. } \\
\text { Abstract }\end{array}$ \\
\hline $\begin{array}{l}\text { Keywords: } \\
\text { eduparent, parents, } \\
\text { independence, early } \\
\text { childhood. }\end{array}$ & $\begin{array}{l}\text { The main purpose of this community service activity is to provide parental education } \\
\text { to parents of students at the Dharma Wanita Suluk Kindergarten in Madiun Regency. } \\
\text { The service method is carried out by conducting socialization through eduparent } \\
\text { seminars (parental education). The eduparent theme in this service activity is to train } \\
\text { the independence of early childhood. The target of this service is the parents of } \\
\text { students at the Dharma Wanita Suluk Kindergarten in Madiun Regency. The results } \\
\text { of this service activity are parents of students able to know and understand their role } \\
\text { in caring for and treating children, especially in training the independence of early } \\
\text { childhood. Parents of students are very enthusiastic in participating in the activities } \\
\text { from the beginning to the end, so they get insight into training the independence of } \\
\text { early childhood in accordance with the stages of development. } \\
\text { Keywords: eduparent, parents, independence, early childhood. }\end{array}$ \\
\hline
\end{tabular}

(C) 2018 FKIP Universitas Slamet Riyadi

Alamat korespondensi: Jl. Budi Utomo No.10, ISSN 2528-3359 (Print) Ronowijayan, Siman, Kabupaten Ponorogo, ISSN2528-3367 (Online) Jawa Timur

E-mail: fadly_ok@yahoo.co.id 


\section{PENDAHULUAN}

Dalam kehidupan anak usia dini peran pengasuhan yang pertama dan utama ialah kedua orang tua. Morrison (2012:34) berpendapat bahwa sistem keluarga memiliki tanggungjawab utama dalam memenuhi kebutuhan anak. Orang tua adalah guru pertama anak. Pengalaman dan bimbingan yang diberikan orang tua dapat membentuk kehidupan anak. Untuk itu, orang tua berkewajiban merawat, membimbing, dan memberikan pendidikan yang terbaik untuk anaknya. Menurut Lestari (2016:39) pengasuhan harus dijalankan bedasarkan kesadaran pengasuhan anak, yaitu suatu kesadaran bahwa pengasuhan anak merupakan sarana untuk mengoptimalkan potensi anak, mengarahkan anak pada pencapaian kesejahteraan, dan membantu anak dalam menyelesaikan tugas-tugas perkembangannya dalam setiap tahap kehidupannya dengan baik. Perkembangan anak sesungguhnya dimulai dalam sistem keluarga (Morrison, 2012:35). Sistem keluarga dengan bantuan dan dukungan dari program anak usia dini dapat menyediakan dan memfasilitasi kebutuhan dasar anak.

Pola asuh yang diberikan orang tua dan lingkungannya dapat mempengaruhi kehidupan dan masa depan seorang anak. Apa saja yang diberikan orang tua kepada anak akan menjadi dasar bagi perkembangan anak selanjutnya. John Amos Comenius (1952-1670) berpendapat bahwa pengalaman anak menentukan akan menjadi apa mereka kelak (Morrison, 2012: 62). Selain itu, pengasuhan yang terampil dapat merangsang perkembangan intelektual anak (Brooks, 2011:37). Mengingat begitu pentingnya parenting bagi anak usia dini, maka diperlukan pola parenting yang dapat mengembangkan berbagai potensi anak.

Terkait persoalan tersebut ternyata masih banyak orang tua yang belum mengerti bagaimana cara mengasuh anak yang baik dan dapat mengembangkan potensi anak. Masih banyak orang tua yang memperlakukan anak secara diskriminasi, bahkan tidak sedikit yang melakukan kekerasan terhadap anak. Oleh karena itu, dibutuhkan pendidikan keorangtuaan, supaya setiap orang tua memiliki bekal dalam mengasuh dan mendidik anaknya. Dalam konteks ini perlu diadakan sosialisasi dan seminar tentang pendidikan keorangtuaan.

\section{PERMASALAHAN MITRA}

Permasalahan khusus yang sedang di hadapai sebagian orang tua di TK Dharma Wanita Suluk Dlopo Kabupaten Madiun adalah (1) orang tua siswa belum mengetahui dan memahami cara mengasuh anak sesuai dengan tahap perkembangannya, terutatama dalam melatih kemandirian anak usia dini; (2) minimnya sosialisasi maupun seminar tentang pendidikan keorangtuaan yang diikuti oleh orang tua siswa di TK Dharma Wanita Suluk Dlopo Kabupaten Madiun. Meskipun buku-buku tentang parenting sudah tersedia, namun sebagian orang tua belum memiliki, lebih-lebih membacanya. Selain itu, wawasan tentang pengasuhan terbatas dan cenderung konvensional yang diwarisi secara turun temurun dari orang tuanya terdahulu.

Berdasarkan permasalah yang dialami oleh mitra tersebut maka dibuat kegiatan pengabdian kepada masyarakat dengan tema eduparent bagi orang tua siswa di TK Dharma Wanita Suluk Dlopo Kabupaten Madiun. Agar kegiatan ini dapat berjalan dengan baik, maka harus dibuat program strategis yang melibatkan berbagai komponen yang terkait dengan program pengabdian masyarakat. Adapun yang dilibatkan dalam kegiatan ini ialah kepala sekolah dan guru-guru TK Dharma Wanita Suluk Dlopo Kabupaten Madiun.

\section{METODE}

Eduparent (pendidikan keorangtua) dalam program pengabdian masyarakat ini dilaksanakan dan dikemas dalam bentuk seminar. Di mana terdapat narasumber yang memberikan materi dan ada peserta yang mendengarkan dan menerima materi. 
Narasumber dalam kegiatan ini yaitu $M$. Fadlillah, M.Pd.I dosen pendidikan guru pendidikan anak usia dini Universitas Muhammadiyah Ponorogo. Adapun pesertanya yaitu orang tua siswa di TK Dharma Wanita Suluk Dlopo Kabupaten Madiun, baik kelompok A maupun kelompok B. Kegiatan ini diikuti oleh 30 orang tua siswa dan beberapa guru di TK Dharma Wanita Suluk Dlopo. Adapun waktu pelaksanaanya yaitu hari Sabtu tanggal 22 September 2018 yang bertempat di aula TK Dharma Wanita Suluk Dlopo Kabupaten Madiun. Pelaksanaan kegiatan eduparent ini dapat dilihat melalui gambar 1 .

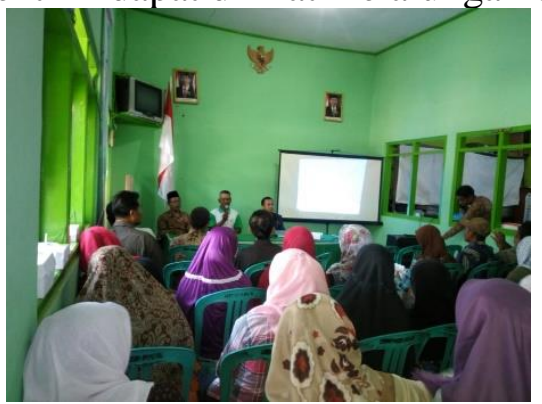

Gambar 1. Pelakasanaan eduparent di TK Dharma Wanita Suluk Dlopok

\section{HASIL DAN PEMBAHASAN}

Kegiatan eduparent ini dimaksudkan untuk memberikan edukasi kepada orang tua siswa di TK Dharma Wanita Suluk Dlopo Kabupaten Madiun tentang cara mengasuh dan memperlakukan anak usia dini sesuai dengan tahap perkembangannya. secara khusus tema kegiatan eduparent ini yaitu melatih kemandiran anak usia dini. dengan kegiatan eduparent ini diharapkan orang tua dapat lebih mudah dalam mengasuh dan mendidik, terutama dalam melatih kemandirian anak-anak mereka. Sebab, orang tua merupakan pendidik pertama dan utama bagi anak-anaknya. Sebagaimna dikemukakan oleh Morrison (2012:34) yang menyebutkan bahwa sistem keluarga memiliki tanggungjawab utama dalam memenuhi kebutuhan anak. Sistem keluarga meliputi bapak dan ibu yang berperan dalam pengasuhan anak tersebut.
1. Pelaksanaan eduparent di TK Dharma Wanita Suluk Dlopo

Kegiatan eduparent di TK Dharma Wanita Suluk Dlopo Kabupaten Madiun dilaksanakan dengan tema 'Melatih Kemandirian Anak Usia Dini'. Dalam kesempatan tersebut narasumber memberikan penjelasan tentang langkahlangkah dalam menanamkan kemandirian pada anak usia dini. Fadlillah sebagai narasumber menjelaskan bahwa kemandirian anak dapat dilatih melalui kegiatan sehari-hari di rumah, seperti: mandi, gosok gigi, memakai baju, celana, dan sepatu, serta aktivitas makan dan minum.

Dalam pelasaksanaan seminar eduparent, peserta yang terdiri dari orang tua siswa TK Dharma wanita Suluk Dlopo sangat antusias mengikuti jalannya seminat. Terbutkti peserta dapat mengikuti kegiatan dari awal sampai akhhir dan mendengarkan dengan sangat baik, serta beberpa peserta sangat antusias bertanya kepada narasumber pada sesi tanya jawab. Suasana pelaksanaan eduparent ini dapat dilihat melalui gambar 2 .

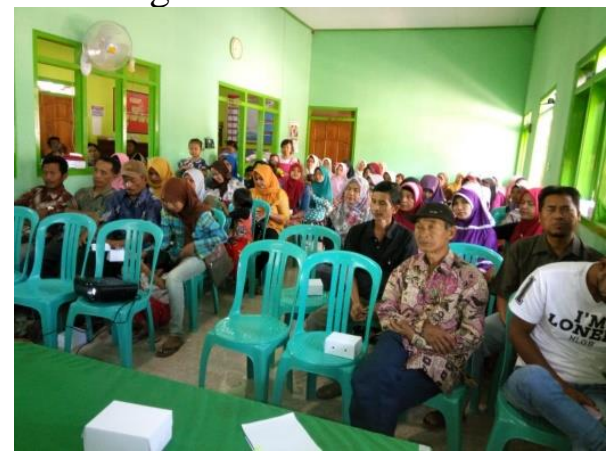

Gambar 2. Antusias peserta dalam

mendengarkan kegiatan eduparent

2. Melatih kemandirian anak usia dini

Dalam kegiatan eduparent yang berlangsung di TK Dharma Wanita Suluk Dlopo disampaikan bahwa kemandirian anak dapat dilatih melalui kegiatan pembiasaan dan aktivitas sehari-hari. 
Orang tua dapat mengajarkan anak cara berpakaian, makan, mandi, dan gosok gigi secara mandiri. Di samping itu, orang tua harus memberikan kepercayaan kepada anak serta berani melepaskan anak untuk belajar di sekolah tanpa ditemani atau ditunggui. Biarkan anak bereksplorasi dan menunjukkan kemandiriannya sesuai dengan kemampuannya masing-masing. Melatih kemandirian anak usia dini dapat disesuaikan dengan tahap perkembangannya. Menurut Kementerian Kesehatan Republik Indonesia (2016) ada beberapa langkah dalam melatih kemandirian anak, di antaranya:

a. Melatih kemandirian anak usia 12-18 bulan

Pada usia ini kemandirian anak dapat dilatih dengan cara mengajak anak menirukan perkerjaan rumah tangga. Ketika Anda membersihakan rumah, menyapu dan memasak atau yang lainnya, ajak anak untuk menirukan. Di samping itu, ajari anak melepas pakaian, makan dan minum sendiri, serta merawat boneka. Boneka dapat dijadikan sarana dalam belajar umenggendong, memberi makan, menyayangi, dan memandikannya.

b. Melatih kemandirian anak usia 18-24 bulan

Pada usia ini kemandirian anak dapat dilatih dengan cara mengajari anak mengancingkan kancing baju, membuat rumah-rumahan, berpakaian, dan mulai mengenalkan jenis kelamin.

c. Melatih kemandirian anak usia 24-36 bulan

Pada usia ini kemadirian anak dapat dilatih dengan cara toilet training, berbapakaian sendiri tanpa bantuan, membersihkan tubuhnya ketika kotor, dan biarkan anak memilih pakiannya sendiri untuk dikenakan. d. Melatih kemandirian anak usia 36-48 bulan

Pada usia ini kemandirian anak dapat dilatih dengan cara makan dan minum sendiri, menggunakan sendok garpu, dan biarkan anak membantu memasak sesuai dengan kemampuannya.

e. Melatih kemandirian anak usia 48-60 bulan

Pada usia ini kemandirian anak dapat dapat dilatih dengan cara memberikan tugas rutin pada anak dalam kegiatan rumah, ajak anak membantu anda di dapur dan makan bersama keluarga. Memberi kesempatan pada anak untuk mengunjungi tetangga dekat, teman, saudara tanpa ditemani, selanjutnya minta anak bercerita tentang kunjungannya.

f. Melatih kemandirian anak usia 60-72 bulan

Pada usia ini dorong agar anak berpakaian sendiri, menyimpan mainan sendiri tanpa bantuan, dan minta anak membantu kegiatan di rumah seperti memasak dan bersihbersih rumah. Buat peraturan keluarga yang melibatkan anak dalam pertemuan tersebut dan minta anak untuk mematuhi peraturan-peraturan dalam keluarga. Hindari penggunaan kekerasan/hukuman badan, ketika anak melanggarnya.

Eduparent tentang melatih kemandirian anak usia dini tersebut diikuti orang tua dengan sangat baik. Beberapa guru dan orang tua siswa berharap kegiatan serupa dapat diadakan secara rutin di tahun-tahun selanjutnya.

\section{KESIMPULAN}

Dari kegiatan pengabdian kepada masyarakat tentang eduparent bagi orang tua siswa di TK Dharma Wanita Suluk Dlopo Kabupaten Madiuan dapat disimpulkan bahwa sosialisasi atau seminar eduparent dapat menambah 
M. Fadlillah, Eduparent Bagi Orang Tua Siswa TK Dharma Wanita Suluk Dlopo Kabupaten Madiun

wawasan orang tua dalam mengasuh dan melatih kemandirian anak usia dini. Orang tua siswa sangat bersemangat dari awal hingga akhir kegiatan. wawan kemandirian yang dapat diajarkan kepada anak di antaranya mandi, gosok gigi, memakai baju, celana, dan sepatu, makan dan minum, serta aktivitas pembiasaan sehari-hari

\section{DAFTAR PUSTAKA}

Arikunto, Suharsimi. 2002. Prosedur Penelitian; Suatu Pendekatan Praktek. Jakarta: Rineka Cipta.

Sudijono, Anas. 2005. Pengantar Evaluasi Pendidikan. Jakarta: Raja Grafindo Persada.

Brooks, J. (2011). The Process of Parenting: Edisi Kedelapan. (Terjemahan Rahmat Fajar). Yogyakarta: Pustaka Pelajar. (Edisi asli diterbitkan tahun 2011 oleh McGraw-Hill, on Imprint of The McGraw-Hill, Inc, New York).
Kementerian Kesehatan RI. (2016). Pedoman Pelaksanaan Stimulasi Deteksi dan Intervensi Dini Tumbuh Kembang Anak.

Lestari, S. (2014). Psikologi Keluarga: Penanaman Nilai dan Penangan Konflik dalam Keluarga. Jakarta: Kencana.

Morrison, G. S. (2012). Dasar-Dasar Pendidikan Anak Usia Dini. Edisi Kelima. (Penerjemah Suci Romadhona dan Apri Widiastuti). Jakarta: Indeks. (Edisi asli diterbitkan tahun 2008 oleh Pearson Education, Inc).

Undang-Undang Nomor 20 Tahun 2003 tentang Sistem Pendidikan Nasional. 